\title{
Phenacenes from Diels-Alder Trapping of Photogenerated o- Xylylenols: Phenanthrenes and Benzo[e]pyrene Bisimide
}

\author{
Faysal Ilhan, Daniel S. Tyson, and Michael A. Meador \\ Polymers Branch, Materials Division \\ NASA Glenn Research Center, \\ 21000 Brookpark Road, \\ Cleveland, Ohio 44135,
}

And

Ohio Aerospace Institute, 22800 Cedar Point Road,

Cleveland, Ohio 44142 


\section{Synthesis}

\section{Materials.}

Synthesis of the diketone, 2,3-dimethyl-1,4-dibenzoylbenzene 3, followed a previously reported scheme. ${ }^{1}$ Reagent grade tetrahydrofuran was purchased from Aldrich and dried over sodium/benzophenone prior to use. All other reagents were purchased from Aldrich and used as received. All ${ }^{1} \mathrm{H}$ NMR and ${ }^{13} \mathrm{C}$ NMR spectra were recorded in either $\mathrm{CDCl}_{3}$ or $\mathrm{d}_{6}$-DMSO as indicated. Flash column chromatography was performed on silica with an Argonaut Flash Master II system equipped with a UV-Vis absorption detector. The melting points presented are uncorrected. Elemental analysis was obtained by Atlantic Microlabs, Inc. (Norcross, GA).

\section{Synthesis of Phenanthrene Bisimides.}

\section{Tetramethyl-4,7-dihydroxy-4,7-diphenyl-1,2,3,8,9,10-octahydrophenanthrene-}

2,3,8,9-tetracarboxylate (4a). A $330 \mathrm{ml}$ benzene solution of 2,3-dimethyl-1,4dibenzoylbenzene 3 (2 g, $6.37 \mathrm{mmol})$ and dimethyl fumarate $(2.3 \mathrm{~g}, 15.97 \mathrm{mmol})$ was irradiated for $18 \mathrm{hrs}$ (the solution was previously degassed with a stream of nitrogen for $45 \mathrm{~min}$ and the stirred solution was then irradiated using a $450 \mathrm{~W}$ medium pressure $\mathrm{Hg}$ lamp (Hanovia) equipped with a Pyrex filter). The solvent was removed under vacuum and the crude product was then triturated with $75 \mathrm{ml}$ of methanol to yield a white solid product in $57 \%$ yield $(2.18 \mathrm{~g}) .{ }^{1} \mathrm{H}$ NMR $\left(200 \mathrm{MHz} \mathrm{CDCl}_{3}\right): \delta 3.38(\mathrm{~s}, 3 \mathrm{H}), 3.39(\mathrm{~s}, 3 \mathrm{H})$, 3.3.74 (s, 3H), 3.75 (s, 3H), 2.9-4.2 (m, 8H), $6.53(\mathrm{~s}, 2 \mathrm{H}), 7.0-7.2(\mathrm{~m}, 12 \mathrm{H}) .{ }^{13} \mathrm{C} \mathrm{NMR}$

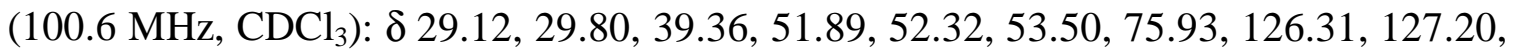
127.80, 128.07, 128.26, 131.63, 139.20, 139.57, 144.36, 144.68, 174.18, 174.36, 174.76.

\section{$N, N^{\prime}$-Bis(phenyl)-4,7-dihydroxy-4,7-diphenyl-1,2,3,8,9,10-octahydrophenanthrene-}

2,3,8,9-tetracarboxylic diimide (4b). A $330 \mathrm{ml}$ benzene solution of 2,3-dimethyl-1,4dibenzoylbenzene 3 ( $2 \mathrm{~g}, 6.37 \mathrm{mmol})$ and $N$-phenyl maleimide $(2.31 \mathrm{~g}, 13.35 \mathrm{mmol})$ was irradiated for $18 \mathrm{hrs}$ (the solution was previously degassed with a stream of nitrogen for $45 \mathrm{~min}$ and the stirred solution was then irradiated using a $450 \mathrm{~W}$ medium pressure $\mathrm{Hg}$ lamp (Hanovia) equipped with a Pyrex filter). The solvent was removed under vacuum 
and the crude product was then triturated with $100 \mathrm{ml}$ of acetonitrile to yield a white solid product in $68 \%$ yield $(2.84 \mathrm{~g}) .{ }^{1} \mathrm{H}$ NMR $\left(200 \mathrm{MHz}, \mathrm{CDCl}_{3}\right): \delta 2.19-2.31(\mathrm{~m}, 2 \mathrm{H}), 3.27-$ $3.45(\mathrm{~m}, 4 \mathrm{H}), 4.19(\mathrm{~d}, 2 \mathrm{H}, \mathrm{J}=8 \mathrm{~Hz}), 5.52(\mathrm{~s}, 2 \mathrm{H}), 6.8-7.2(\mathrm{~m}, 20 \mathrm{H}), 8.08(\mathrm{~s}, 2 \mathrm{H}) .{ }^{13} \mathrm{C}$ NMR (50.3 MHz, $\left.\mathrm{CDCl}_{3}\right): \delta 25.72,39.43,47.27,77.02,124.80,126.28,126.72,128.63$, $128.85,129.12,129.37,129.56,130.85,131.10,141.01,141.87,178.35,179.74$.

\section{Tetramethyl-4,7-dihydroxy-4,7-diphenyl-1,10-tetrahydrophenanthrene-2,3,8,9-}

tetracarboxylate (4d). A $330 \mathrm{ml}$ benzene solution of 2,3-dimethyl-1,4dibenzoylbenzene 3 (2 g, $6.37 \mathrm{mmol})$ and dimethyl acetylene dicarboxylate $(9.26 \mathrm{~g}$, $65.13 \mathrm{mmol}$ ) was irradiated for $18 \mathrm{hrs}$ (the solution was previously degassed with a stream of nitrogen for $45 \mathrm{~min}$ and the stirred solution was then irradiated using a $450 \mathrm{~W}$ medium pressure $\mathrm{Hg}$ lamp (Hanovia) equipped with a Pyrex filter). The solvent was removed under vacuum and the crude product was then triturated with $75 \mathrm{ml}$ of methanol to yield a cream colored solid product in $30 \%$ yield $(1.14 \mathrm{~g}) .{ }^{1} \mathrm{H}$ NMR (300 $\mathrm{MHz}$, $\left.\mathrm{CDCl}_{3}\right): \delta 3.5-4.2(\mathrm{~m}, 16 \mathrm{H}), 7.14-7.31(\mathrm{~m}, 12 \mathrm{H}) .{ }^{13} \mathrm{C} \mathrm{NMR}\left(75.4 \mathrm{MHz}, \mathrm{CDCl}_{3}\right): \delta 28.57$, 28.68, 52.39, 52.46, 52.73, 74.03, 74.06, 125.38, 125.53, 126.49, 126.54, 127.26, 127.30, $127.39,127.45,128.15,128.25,131.16,131.41,137.68,137.86,138.35,138.51,144.85$, $144.91,167.24,167.76$.

\section{$N, N^{\prime}$-Bis(octyl)-4,7-dihydroxy-4,7-diphenyl-1,2,3,8,9,10-octahydrophenanthrene-}

2,3,8,9-tetracarboxylic diimide (4c): A solution of the 2,3-dimethyl-1,4dibenzoylbenzene 3 ( $1 \mathrm{~g}, 3.19 \mathrm{mmol})$ and N-octyl maleimide $(1.37 \mathrm{~g}, 6.55 \mathrm{mmol})$ in 330 $\mathrm{ml}$ of benzene was vigorously degassed under $\mathrm{N}_{2}$ for 45 minutes in a reactor fitted with a reflux condenser. The $\mathrm{N}_{2}$ flow was reduced and the solution was stirred for 16 hours using a $450 \mathrm{~W}$ medium pressure $\mathrm{Hg}$ lamp (Hanovia) equipped with a Pyrex filter. The solvent was removed in vacuo and the resulting crude product was triturated with $\mathrm{CH}_{3} \mathrm{OH}$ to yield the desired off-white colored product as a mixture of possible isomers $(1.9 \mathrm{~g}$, 86\% yield). ${ }^{1} \mathrm{H}$ NMR (300 MHz, $\left.\mathrm{CDCl}_{3}\right): \delta 0.85-0.88(\mathrm{~m}, 6 \mathrm{H}), 1.0-1.4(\mathrm{~m}, 24 \mathrm{H}), 2.1-2.4$ (m, 2H), 3.1-3.4 (m, 8H), 3.9-4.0 (m, 2H), 5.16,5.44 (s,s, 2H), 7.0-7.4 (m, 10H), 7.81, $7.94(\mathrm{~s}, \mathrm{~s}, 2 \mathrm{H}) .{ }^{13} \mathrm{C} \mathrm{NMR}\left(75.4 \mathrm{MHz}, \mathrm{CDCl}_{3}\right): \delta 14.03,22.59,22.62,24.69,24.89,26.54$, 26.73, 27.18, 27.3, 28.64, 28.97, 29.14, 31.71, 31.77, 38.72, 38.90, 38.93, 38.97, 47.09, 
$47.59,124.41,126.53,126.68,128.26,128.36,128.65,137.71,131.27,141.31,131.46$, $131.65,178.20,178.91,179.64,180.13$.

Tetramethyl-4,7-diphenyl-1,2,9,10-hexahydrophenanthrene-2,3,8,9-tetracarboxylate (5a). A solution of $4 \mathbf{a}(1.5 \mathrm{~g}, 2.49 \mathrm{mmol})$ and catalytic amount of $p$-toluene sulfonic acid monohydrate $(0.275 \mathrm{~g}, 1.45 \mathrm{mmol})$ in $150 \mathrm{ml}$ of toluene was refluxed under nitrogen for $18 \mathrm{hrs}$. The resulting solution was allowed to cool down to room temperature. Then it was washed twice with $30 \mathrm{ml}$ portions of a solution of $\mathrm{NaOH}(5 \%$, aq.) and once with 30 $\mathrm{ml}$ of distilled $\mathrm{H}_{2} \mathrm{O}$. The organic layer was dried over $\mathrm{Na}_{2} \mathrm{SO}_{4}$ and evaporated to dryness in vacuo to afford an off-white solid product in $64 \%$ yield $(0.9 \mathrm{~g}) .{ }^{1} \mathrm{H}$ NMR $(200 \mathrm{MHz}$, $\left.\mathrm{CDCl}_{3}\right): \delta 3.45(\mathrm{~s}, 6 \mathrm{H}), 3.66(\mathrm{~s}, 3 \mathrm{H}), 3.67(\mathrm{~s}, 3 \mathrm{H}), 3.0-4.1(\mathrm{~m}, 6 \mathrm{H}), 6.50(\mathrm{~s}, 2 \mathrm{H}), 7.0-7.2$ $(\mathrm{m}, 12 \mathrm{H}) .{ }^{13} \mathrm{C} \mathrm{NMR}\left(50.30 \mathrm{MHz}, \mathrm{CDCl}_{3}\right): \delta 27.36,27.73,41.18,41.43,51.90,52.76$, $125.11,127.43,127.52$, 128.23, 128.51, 128.81, 131.68, 131.75, 135.91, 136.07, 138.85, 147.64, 147.70, 168.08, 173.39, 173.60.

\section{$N, N^{\prime}$-Bis(phenyl)-4,7-diphenyl-1,2,9,10-hexahydrophenanthrene-2,3,8,9-}

tetracarboxylic diimide (5b). A solution of $\mathbf{4 b}(1.5 \mathrm{~g}, 2.27 \mathrm{mmol})$ and catalytic amount of $p$-toluene sulfonic acid monohydrate $(0.25 \mathrm{~g}, 1.31 \mathrm{mmol})$ in $150 \mathrm{ml}$ of toluene was refluxed under nitrogen for $18 \mathrm{hrs}$. The resulting solution was allowed to cool down to room temperature. Then it was washed twice with $30 \mathrm{ml}$ portions of a solution of $\mathrm{NaHCO}_{3}$ (sat., aq.) and twice with $30 \mathrm{ml}$ of distilled $\mathrm{H}_{2} \mathrm{O}$. The organic layer was dried over $\mathrm{Na}_{2} \mathrm{SO}_{4}$ and evaporated to dryness in vacuo to afford yellow crude solid product. The crude product purified by a flash column chromatography (Hex (2.5)/EtOAc (1)) to yield an off-white solid product in $65 \%$ yield $(0.92 \mathrm{~g}) .{ }^{1} \mathrm{H} \mathrm{NMR}\left(200 \mathrm{MHz}, \mathrm{CDCl}_{3}\right):{ }^{1} \mathrm{H}$ NMR $\left(200 \mathrm{MHz}, \mathrm{CDCl}_{3}\right): \delta 2.9-3.9(\mathrm{~m}, 6 \mathrm{H}), 6.93(\mathrm{~s}, 2 \mathrm{H}), 7.3-7.5(\mathrm{~m}, 20 \mathrm{H}) .{ }^{13} \mathrm{C} \mathrm{NMR}$ $\left(100.6 \mathrm{MHz}_{\mathrm{CDCl}}\right): \delta 25.15,40.12,122.64,126.46,127.85,128.47,128.62,128.95$, $129.30,131.79,133.93,134.22,137.57,146.36,165.63,174.41$.

\section{$N, N^{\prime}$-Bis(octyl)-4,7-diphenyl-1,2,9,10-hexahydrophenanthrene-2,3,8,9-}

tetracarboxylic diimide (5c): A solution of the photoadduct $4 \mathbf{c}(1.77 \mathrm{~g}, 2.56 \mathrm{mmol})$ and p-toluene sulfonic acid monohydrate (p-TSA, $0.40 \mathrm{~g}, 2.10 \mathrm{mmol}$ ) in $175 \mathrm{ml}$ of toluene 
was refluxed for 16 hours. The resulting solution was evaporated to dryness under vacuum. Methanol was added to the resulting crude product and the mixture was stirred to dissolve p-TSA. The mixture was filtered to collect the solid product, which was then used in the following aromatization step without any further purification $(1.41 \mathrm{~g}, 84 \%$ yield). ${ }^{1} \mathrm{H}$ NMR $\left(300 \mathrm{MHz}, \mathrm{CDCl}_{3}\right): \delta 0.87$ (t, 6H, J=6 Hz), 1.2-1.4 (m, 20H), 1.5-1.7 $(\mathrm{m}, 4 \mathrm{H}), 2.6-2.9(\mathrm{~m}, 2 \mathrm{H}), 3.4-3.9(\mathrm{~m}, 8 \mathrm{H}), 6.8-7.4(\mathrm{~m}, 12 \mathrm{H}) .{ }^{13} \mathrm{C} \mathrm{NMR}(75.4 \mathrm{MHz}$, $\left.\mathrm{CDCl}_{3}\right): \delta 14.05,22.62,25.13,25.77,27.00,27.89,29.14,29.15,31.77,38.87,40.05$, 40.12 , 123.35, 127.80, 127.92, 128.36, 128.60, 129.12, 129.20, 130.16, 133.94, 133.97, $134.51,137.51,137.79,144.92,144.97,166.64,166.69,175.17,175.34$.

\section{Tetramethyl-4,7-diphenyl-phenanthrene-2,3,8,9-tetracarboxylate (1a).}

(a) A solution of 5a $(0.7 \mathrm{~g}, 1.24 \mathrm{mmol})$ and DDQ (2,3-dichloro-5,6-dicyano-1,4benzoquinone) ( $0.59 \mathrm{~g}, 2.6 \mathrm{mmol})$ in $60 \mathrm{ml}$ of chlorobenzene was refluxed under nitrogen for $18 \mathrm{hrs}$. The resulting mixture was allowed to cool down to room temperature. Then it was washed three times with $50 \mathrm{ml}$ portions of a solution of $\mathrm{NaOH}(5 \%$, aq.) and once with $50 \mathrm{ml}$ of distilled $\mathrm{H}_{2} \mathrm{O}$. The organic layer was dried over $\mathrm{Na}_{2} \mathrm{SO}_{4}$ and evaporated to dryness in vacuo to afford a pale yellow solid product in $81 \%$ yield $(0.56 \mathrm{~g})$. Mp 233$234{ }^{\circ} \mathrm{C} .{ }^{1} \mathrm{H} \mathrm{NMR}\left(200 \mathrm{MHz}, \mathrm{CDCl}_{3}\right): \delta 3.59(\mathrm{~s}, 6 \mathrm{H}), 4.04(\mathrm{~s}, 6 \mathrm{H}), 7.2-7.5(\mathrm{~m}, 12 \mathrm{H}), 9.53$ $(\mathrm{s}, 2 \mathrm{H}) .{ }^{13} \mathrm{C} \mathrm{NMR}\left(50.3 \mathrm{MHz}, \mathrm{CDCl}_{3}\right): \delta 52.61,53.25,125.85,127.86,128.41,128.54$, $130.08,130.48,133.66,133.81,136.53,139.68,166.47,169.25$. Calculated for $\mathrm{C}_{34} \mathrm{H}_{26} \mathrm{O}_{8} ; \mathrm{C}: 72.59, \mathrm{H}: 4.66$; found $\mathrm{C}: 72.97, \mathrm{H}: 4.61$.

(b) A solution of $4 \mathbf{c}(0.25 \mathrm{~g}, 0.42 \mathrm{mmol})$ and catalytic amount of $p$-toluene sulfonic acid $(0.05 \mathrm{~g}, 0.26 \mathrm{mmol})$ in $25 \mathrm{ml}$ of toluene was refluxed under nitrogen for $18 \mathrm{hrs}$. The resulting mixture was allowed to cool down to room temperature. Then it was washed two times with $30 \mathrm{ml}$ portions of a solution of $\mathrm{NaOH}(5 \%$, aq.) and once with $30 \mathrm{ml}$ of distilled $\mathrm{H}_{2} \mathrm{O}$. The organic layer was dried over $\mathrm{Na}_{2} \mathrm{SO}_{4}$ and evaporated to dryness in vacuo to afford a pale yellow solid product in $77 \%$ yield $(0.18 \mathrm{~g})$. See part a for analysis.

$N, N^{\prime}$-Bis(phenyl)-4,7-diphenyl phenanthrene-2,3,8,9-tetracarboxylic diimide (1b). 
A solution of $5 \mathbf{b}(0.35 \mathrm{~g}, 0.56 \mathrm{mmol})$ and DDQ (2,3-dichloro-5,6-dicyano-1,4benzoquinone) $(0.27 \mathrm{~g}, 1.19 \mathrm{mmol})$ in $30 \mathrm{ml}$ of chlorobenzene was refluxed under nitrogen for $18 \mathrm{hrs}$. The resulting mixture was allowed to cool down to room temperature. Then it was washed three times with $50 \mathrm{ml}$ portions of a solution of $\mathrm{NaOH}$ (5\%, aq.) and once with $50 \mathrm{ml}$ of distilled $\mathrm{H}_{2} \mathrm{O}$. The organic layer was dried over $\mathrm{Na}_{2} \mathrm{SO}_{4}$ and evaporated to dryness in vacuo to dryness. Recrystallization over $\mathrm{CH}_{3} \mathrm{OH} / \mathrm{CH}_{2} \mathrm{Cl}_{2}$ afforded a pale yellow solid product in $72 \%$ yield $(0.25 \mathrm{~g}) . \quad \mathrm{Mp} 401{ }^{\circ} \mathrm{C} .{ }^{1} \mathrm{H}$ NMR (200 $\left.\mathrm{MHz}_{\mathrm{CDCl}}\right): \delta$ 7.2-7.6 (m, 20H), $7.88(\mathrm{~s}, 2 \mathrm{H}), 9.53(\mathrm{~s}, 2 \mathrm{H}) .{ }^{13} \mathrm{C} \mathrm{NMR}(50.3 \mathrm{MHz}$, $\left.\mathrm{CDCl}_{3}\right): \delta 119.99,126.34,126.90,128.54,128.66,129.15,129.31,129.68,130.11$, 131.87, 134.15, 134.62, 136.04, 141.13, 166.29, 166.84. Calculated for $\mathrm{C}_{42} \mathrm{H}_{24} \mathrm{~N}_{2} \mathrm{O}_{4}$; $\mathrm{C}: 81.28, \mathrm{H}: 3.90, \mathrm{~N}: 4.51$; found $\mathrm{C}: 80.96, \mathrm{H}: 3.68, \mathrm{~N}: 4.50$.

$N, N^{\prime}$-Bis(octyl)-4,7-diphenyl-2,3,8,9-tetracarboxylic diimide (1c): A solution of the dehydrated photoadduct 5c $(0.70 \mathrm{~g}, 1.0 \mathrm{mmol})$ and DDQ $(0.48 \mathrm{~g}, 2.11 \mathrm{mmol})$ in $50 \mathrm{ml}$ chlorobenzene was heated to $140{ }^{\circ} \mathrm{C}$ for 16 hours. The resulting solution was cooled to room temperature and washed with $5 \%$ aq. $\mathrm{NaOH}$ solution, followed by brine. The organic layer was dried over $\mathrm{Na}_{2} \mathrm{SO}_{4}$ and evaporated to dryness in vacuo. The crude product was boiled in $\mathrm{MeOH}$ and the off-white solid product was collected by filtration (0.588 g, 85\% yield). Mp 161-163 ${ }^{\circ} \mathrm{C}$. ${ }^{1} \mathrm{H} \mathrm{NMR}\left(300 \mathrm{MHz}, \mathrm{CDCl}_{3}\right): \delta 0.87(\mathrm{t}, 6 \mathrm{H}, \mathrm{J}=6.0$ $\mathrm{Hz}), 1.2-1.4(\mathrm{~m}, 20 \mathrm{H}), 1.6-1.7(\mathrm{~m}, 4 \mathrm{H}), 3.70(\mathrm{t}, 4 \mathrm{H}, \mathrm{J}=7.5 \mathrm{~Hz}), 7.3-7.6(\mathrm{~m}, 10 \mathrm{H}), 7.82(\mathrm{~s}$, $2 \mathrm{H}), 9.38(\mathrm{~s}, 2 \mathrm{H}) .{ }^{13} \mathrm{C} \mathrm{NMR}\left(75.4 \mathrm{MHz}, \mathrm{CDCl}_{3}\right): \delta$ 14.01, 22.58, 26.97, 28.48, 29.12, $31.74,38.53,118.86,126.50,128.04,128.29$, 128.74, 129.86, 134.05, 134.12, 135.32, 140.03, 167.06, 167.59. Calculated for $\mathrm{C}_{46} \mathrm{H}_{48} \mathrm{~N}_{2} \mathrm{O}_{4} ; \mathrm{C}: 79.74, \mathrm{H}: 6.98, \mathrm{~N}: 4.04$; found C:79.32, H:6.93, N:4.00.

\section{Synthesis of Benzo[e]pyrene.}

1,4-Dichloro anthraquinone (7): To a suspension of phosphorous pentachloride (187.5 g, $0.9 \mathrm{~mol}$ ) in $100 \mathrm{ml}$ of 1,1,2,2-tetrachloroethane, leucoquinizarin 6 (36 g, $0.15 \mathrm{~mol}$ ) was added. The mixture was mechanically stirred under $\mathrm{N}_{2}$ for $18 \mathrm{hrs}$. The resulting mixture was cooled down to room temperature and $75 \mathrm{ml}$ of methanol was added slowly, resulting in a precipitation. This solid was collected by filtration and further dried in a 
vacuum oven. This solid ( $25 \mathrm{~g}$ ) was then refluxed in $200 \mathrm{ml}$ of 1-pentanol for $3.5 \mathrm{hrs}$ and cooled down to room temperature. As the solution cooled down, a precipitation of yellow needles was observed. This yellow solid product was collected by filtration, washed with ethanol and further dried in vacuum (16 g, 39\%). ${ }^{1} \mathrm{H}$ NMR $(300 \mathrm{MHz}$, $\left.\mathrm{CDCl}_{3}\right): \delta 7.68(\mathrm{~s}, 2 \mathrm{H}), 7.70-7.80(\mathrm{~m}, 2 \mathrm{H}), 8.10-8.20(\mathrm{~m}, 2 \mathrm{H}) .{ }^{13} \mathrm{C}$ NMR $(75.4 \mathrm{MHz}$, $\left.\mathrm{CDCl}_{3}\right): \delta 126.91,132.19,133.68,134.01,134.14,137.14,181.59$.

1,4-Dichloro-9,10-dihydro anthracene (8): A mixture of 1,4-dichloro anthraquinone 7 $(12.5 \mathrm{~g}, 45 \mathrm{mmol})$, red phosphorous $(5.63 \mathrm{~g}, 182 \mathrm{mmol})$ and hydroiodic acid (47+\%) (88 $\mathrm{ml}$ ) in $575 \mathrm{ml}$ of glacial acetic acid was refluxed under $\mathrm{N}_{2}$ for 4 days. The resulting mixture was cooled down to room temperature and poured into $1 \mathrm{~L}$ of water to precipitate a violet colored solid. This solid was then collected by filtration, dissolved in $800 \mathrm{ml}$ of $\mathrm{CH}_{2} \mathrm{Cl}_{2}$ and filtered again to collect the filtrate. The filtrate was then washed once with $100 \mathrm{ml}$ of $\mathrm{H}_{2} \mathrm{O}$, dried over $\mathrm{Na}_{2} \mathrm{SO}_{4}$ and concentrated under vacuum to yield a yellow colored, crude solid product. Methanol $(100 \mathrm{ml})$ was added to this solid product and filtered again to collect white colored needles of the desired product $(8.25 \mathrm{~g}, 73 \%) .{ }^{1} \mathrm{H}$ NMR (300 MHz, $\left.\mathrm{CDCl}_{3}\right): \delta 4.09$ (s, 4H), 7.21 (s, $\left.2 \mathrm{H}\right)$, 7.20-7.25 (m, 2H), 7.30-7.35 (m, $2 \mathrm{H}) .{ }^{13} \mathrm{C} \mathrm{NMR}\left(75.4 \mathrm{MHz}, \mathrm{CDCl}_{3}\right): \delta 33.14,126.65,127.62,127.86,131.69,134.10$, 135.76 .

1,4-Dicyano-9,10-dihydroanthracene (9): A mixture of 1,4-dichloro-9,10dihydroanthracene 8 (4 g, $16 \mathrm{mmol})$, tris(dibenzylidene acetone)dipalladium(0) $\left(\mathrm{Pd}_{2}(\mathrm{dba})_{3}\right)(8 \mathrm{~mol} \%, 1.184 \mathrm{~g}), 1,1$ '-bis(diphenylphosphino) ferrocene (dppf) (16 mol\%, $1.432 \mathrm{~g}$ ), zinc (48 mol\%, $0.512 \mathrm{~g}$ ), and zinc cyanide (4.56 g, $38.8 \mathrm{mmol}$ ) in $80 \mathrm{ml}$ of dry dimethyl acetamide (DMAC) was stirred under $\mathrm{N}_{2}$ at $150{ }^{\circ} \mathrm{C}$ for 2 days. The resulting mixture was cooled down to room temperature and poured into $700 \mathrm{ml}$ of water to precipitate a brown colored solid. This solid was then collected by filtration, dissolved in $900 \mathrm{ml}$ of $\mathrm{CH}_{2} \mathrm{Cl}_{2}$ and filtered again to collect the filtrate. The filtrate was then washed once with $100 \mathrm{ml}$ of $\mathrm{H}_{2} \mathrm{O}$, dried over $\mathrm{Na}_{2} \mathrm{SO}_{4}$ and concentrated under vacuum to yield a brown colored, crude solid product. This was further purified by flash column chromatography (gradient: $100 \%$ hexane to $100 \%$ ethyl acetate at $1 \%$ per minute) to yield 
a yellow colored solid product $(2.7 \mathrm{~g}, 73 \%) .{ }^{1} \mathrm{H}$ NMR $\left(300 \mathrm{MHz}, \mathrm{CDCl}_{3}\right) \delta 4.24(\mathrm{~s}, 4 \mathrm{H})$, 7.20-7.40 (m, 4H), 7.65 (s, 2H). $\left.{ }^{13} \mathrm{C} \mathrm{NMR} \mathrm{(75.4} \mathrm{MHz,} \mathrm{CDCl}_{3}\right)$ : $\delta 34.18,115.64,116.39$, $127.40,127.83,130.41,132.80,141.82$.

1,4-Dicarboxylic acid-9,10-dihydroanthracene (10): A mixture of 1,4-dicyano-9,10dihydroanthracene 9 (1.6 g, $6.95 \mathrm{mmol})$ and $\mathrm{KOH}(5.73 \mathrm{~g}, 102 \mathrm{mmol})$ in $30 \mathrm{ml}$ of ethanol was refluxed for $18 \mathrm{hrs}$. The resulting mixture was cooled down to room temperature and a mixture of $10 \mathrm{ml}$ of conc. $\mathrm{HCl}$ and $10 \mathrm{ml}$ of $\mathrm{H}_{2} \mathrm{O}$ was added. The mixture was then poured into $150 \mathrm{ml}$ of $\mathrm{H}_{2} \mathrm{O}$ and filtered to collect a yellow solid. According to NMR investigations, this product was assigned as the corresponding bisamide. This solid was then added to a mixture of $30 \mathrm{ml}$ of conc. $\mathrm{HCl}, 30 \mathrm{ml}$ of $\mathrm{H}_{2} \mathrm{O}$ and $40 \mathrm{ml}$ of acetic acid. The resulting mixture was stirred at $125{ }^{\circ} \mathrm{C}$ for 4 days. After cooling down to room temperature, the reaction mixture was poured into $400 \mathrm{ml}$ of $\mathrm{H}_{2} \mathrm{O}$. This was then filtered to collect the dark yellow colored solid product $(1.63 \mathrm{~g}, 88 \%) .{ }^{1} \mathrm{H}$ NMR $(300 \mathrm{MHz}$, DMSO): $\delta 4.26$ (s, 4H), 7.20-7.40 (m, $4 \mathrm{H}), 7.70$ (s, 2H), $13.00\left(\right.$ broad s, 2H). ${ }^{13} \mathrm{C} \mathrm{NMR}$ (75.4 MHz, DMSO): $\delta 32.95,126.25,126.68,127.02,132.95,136.11,138.43,168.75$.

1,4-Dibenzoyl-9,10-dihydro anthracene (11): A solution of 1,4-dicarboxylic acid9,10-dihydro anthracene $\mathbf{1 0}(1.62 \mathrm{~g}, 6.04 \mathrm{mmol})$ in $200 \mu \mathrm{l}$ of dimethyl formamide and 35 $\mathrm{ml}$ of thionyl chloride was refluxed for 3 hours. The resulting solution was evaporated to dryness under vacuum and $50 \mathrm{ml}$ of benzene to obtain a solution. This solution was then added drop wise to a $250 \mathrm{ml}$ round bottom flask containing a mixture of $\mathrm{AlCl}_{3}(3.22 \mathrm{~g}, 24$ mmol) and $75 \mathrm{ml}$ of benzene. The resulting mixture was stirred for 18 hours at room temperature and poured into $200 \mathrm{ml}$ of ice, water mixture containing $20 \mathrm{ml}$ of conc. $\mathrm{HCl}$. Organic layer was separated and the aqueous layer was washed twice with $100 \mathrm{ml}$ portions of benzene. After drying over $\mathrm{Na}_{2} \mathrm{SO}_{4}$, the solution was dried under vacuum to yield a brown colored crude product. This was further purified by running a flash column chromatography to obtain a dark yellow colored oily product $(1.86 \mathrm{~g}, 79 \%) .{ }^{1} \mathrm{H}$ NMR $\left(300 \mathrm{MHz}, \mathrm{CDCl}_{3}\right): \delta 3.96(\mathrm{~s}, 4 \mathrm{H}), 7.00-7.20(\mathrm{~m}, 4 \mathrm{H}), 7.32(\mathrm{~s}, 2 \mathrm{H}), 7.40-7.50(\mathrm{~m}, 4 \mathrm{H})$, 7.55-7.60 (m, 2H), 7.80-7.90 (m, 4H). $\left.{ }^{13} \mathrm{C} \mathrm{NMR} \mathrm{(75.4} \mathrm{MHz,} \mathrm{CDCl}_{3}\right): \delta 33.84,125.38$, $126.44,127.27,128.69,130.29,133.66,135.73,137.08,137.28,139.27,197.85$. 


\section{$N, N^{\prime}$-Bis(octyl)-3,6-dihydroxy-3,6-bis(phenyl)-1,2,7,8,9,14-hexahydro-}

benzo[e]pyrene-1,2,7,8-tetracarboxyl bisimide (12): A solution of 1,4-dibenzoyl9,10-dihydroanthracene 11 (1.92 g, $4.94 \mathrm{mmol})$ and N-octyl maleimide (2.9 g, 10.62 $\mathrm{mmol}$ ) in $330 \mathrm{ml}$ of benzene was vigorously degassed under $\mathrm{N}_{2}$ for 45 minutes in a reactor fitted with a reflux condenser. The $\mathrm{N}_{2}$ flow was reduced and the solution was stirred for 16 hours using a $450 \mathrm{~W}$ medium pressure Hg lamp (Hanovia) equipped with a Pyrex filter. The solvent was removed in vacuo and the resulting crude product was triturated with pentane to yield the desired off-white colored products as a mixture of possible isomers $(3.75 \mathrm{~g}, 81 \%)$. ${ }^{1} \mathrm{H}$ NMR $\left(300 \mathrm{MHz}, \mathrm{CDCl}_{3}\right): \delta 0.86(\mathrm{t}, 6 \mathrm{H}, \mathrm{J}=7.5 \mathrm{~Hz})$, 1.00-1.40 (m, 24H), 3.00-3.20 (m, 4H), $3.73(\mathrm{~m}, 2 \mathrm{H}), 3,93(\mathrm{~d}, 2 \mathrm{H}, \mathrm{J}=6 \mathrm{~Hz}), 4.13$ (d, 2H, $\mathrm{J}=9 \mathrm{~Hz}), 5.80(\mathrm{~s}, 2 \mathrm{H}), 7.10-7.40(\mathrm{~m}, 14 \mathrm{H}), 8.10(\mathrm{~s}, 2 \mathrm{H}) .{ }^{13} \mathrm{C} \mathrm{NMR}\left(75.4 \mathrm{MHz}, \mathrm{CDCl}_{3}\right): \delta$ $13.99,22.53,26.54,27.07,28.59,29.10,31.64,35.23,38.53,44.43,47.44,76.37,124.59$, 126.26, 126.84, 127.91, 128.09, 128.68, 128.96, 131.65, 140.37, 141.00, 175.08, 179.78.

\section{$N, N^{\prime}$-Bis(octyl)-3,6-bis(phenyl)-1,8,9,14-tetrahydro-benzo[e]pyrene-1,2,7,8-}

tetracarboxyl bisimide (13): A solution of the photoadduct $12(0.75 \mathrm{~g}, 0.8 \mathrm{mmol})$ and p-toluene sulfonic acid monohydrate (p-TSA) (0.405 g, $2.1 \mathrm{mmol})$ in $100 \mathrm{ml}$ of toluene was refluxed for 16 hours. Resulting solution was cooled down to room temperature and diluted to $200 \mathrm{ml}$. This was then washed twice with $50 \mathrm{ml}$ portions of $5 \%$ aq. $\mathrm{NaOH}$ and once with $75 \mathrm{ml}$ of brine. After drying over $\mathrm{Na}_{2} \mathrm{SO}_{4}$, it was concentrated under vacuum to yield a dark cream colored solid product (0.69 g, 96\%). ${ }^{1} \mathrm{H}$ NMR (300 MHz, $\left.\mathrm{CDCl}_{3}\right): \delta 0.86(\mathrm{t}, 6 \mathrm{H}, \mathrm{J}=6 \mathrm{~Hz}), 1.00-1.50(\mathrm{~m}, 24 \mathrm{H}), 3.59(\mathrm{t}, 4 \mathrm{H}, \mathrm{J}=12 \mathrm{~Hz}), 3.65(\mathrm{~d}, 2 \mathrm{H}$, $\mathrm{J}=12 \mathrm{~Hz}), 4.67$ (d, 2H, J=12 Hz), 6.90 (s, 2H), 7.30-7.60 (m, 14H). ${ }^{13} \mathrm{C}$ NMR $(75.4 \mathrm{MHz}$, $\left.\mathrm{CDCl}_{3}\right): \delta 14.02,22.59,27.01,27.87,29.12,29.15,29.67,31.72,39.01,39.73,46.17$, $126.55,126.95,127.94,128.35,129.11,130.00,130.64,130.85,131.14,132.76,134.29$, 137.48, 144.56, 166.13, 173.69 .

$N, N^{\prime}$-Bis(octyl)-3,6-bis(phenyl)-benzo[e]pyrene-1,2,7,8-tetracarboxyl bisimide (2): A solution of the dehydrated precursor $13(0.68 \mathrm{~g}, 0.76 \mathrm{mmol})$, sulfur $(0.42 \mathrm{~g}, 13 \mathrm{mmol})$ in $8 \mathrm{ml}$ of diphenylether was refluxed under $\mathrm{N}_{2}$ for four hours. The solution was then 
cooled to room temperature, and $100 \mathrm{ml}$ of hexanes was added. The resulting solid was collected by filtration. Then, the solid was stirred in $100 \mathrm{ml}$ of $\mathrm{CH}_{2} \mathrm{Cl}_{2}$ and filtered to collect the solution portion. The solution was then concentrated in vacuo and further purified by flash column chromatography (gradient: 100\% hexane to $100 \%$ ethyl acetate at $1 \%$ per minute) to yield a cream colored solid product. $(0.35 \mathrm{~g}, 52 \%)$. Mp $247-248{ }^{\circ} \mathrm{C}$. ${ }^{1} \mathrm{H}$ NMR (300 MHz, $\left.\mathrm{CDCl}_{3}\right): \delta 0.86(\mathrm{t}, 6 \mathrm{H}, \mathrm{J}=6 \mathrm{~Hz}), 1.20-1.40(\mathrm{~m}, 10 \mathrm{H}), 1.70-1.80(\mathrm{~m}$, 4H), 3.76 (t, 4H, 7.5 Hz), 7.40-7.50 ( m, 4 H), 7.55-7.65 (m, 6H), 7.75-7.85 (m, 2H), 7.80 $(\mathrm{s}, 2 \mathrm{H}), 9.20-9.30(\mathrm{~m}, 2 \mathrm{H}) .{ }^{13} \mathrm{C} \mathrm{NMR}\left(75.4 \mathrm{MHz} \mathrm{CDCl}_{3}\right): \delta 14.05,22.63,27.09,28.56$, $29.19,31.78,38.77,123.88,128.06,128.23$, 128.29, 128.60, 128.76, 128.99, 130.12, 130.90, 134.30, 134.89, 137.16, 166.92, 168.29. Calculated for $\mathrm{C}_{52} \mathrm{H}_{50} \mathrm{~N}_{2} \mathrm{O}_{4}: \mathrm{C}: 81.43$, $\mathrm{H}: 6.57$; found: $\mathrm{C}: 80.76, \mathrm{H}: 6.53$.

\section{Photophysical}

Analytically pure samples of phenanthrene bisimide $\mathbf{1}$ and benzo[e]pyrene bisimide 2 were used for all experiments. Purification was achieved using flash column chromatography (silica, hexane:ethyl acetate). Optimal separation was accomplished with a gradient profile; $100 \%$ hexane for 5 minutes followed by an increase of $1 \%$ per min of ethyl acetate. Samples were typically dry loaded onto the column by evaporating a concentrated solution onto a minimum amount of silica.

Unless otherwise stated, all experiments used optically dilute solutions (OD < 0.2) at room temperature. Fresh samples were prepared for all measurements by dissolving the appropriate analyte in dichloromethane. Luminescence solutions were prepared under atmospheric conditions and held in anaerobic $1 \mathrm{~cm}^{2}$ quartz cells (Spectracell, FUV) during interrogation. Absorption spectra were measured with a Shimadzu scanning spectrophotometer (UV-3101PC). Emission spectra were obtained with an AmincoBowman luminescence spectrometer (Series 2). The excitation was accomplished with a $150 \mathrm{~W}$ Xe lamp optically coupled to a monochrometer $( \pm 2 \mathrm{~nm})$. The emission was collected at $90^{\circ}$ and passed through a second monochrometer $( \pm 2 \mathrm{~nm})$. Luminescence was measured with a photomultiplier tube $(\mathrm{PMT})$. Radiative quantum yields $\left(\Phi_{\mathrm{r}}\right)$ were 
measured against anthracene for which $\Phi_{\mathrm{r}}=0.27$ in $\mathrm{EtOH}$, accurate to $10 \%,{ }^{1}$ and calculated using the following equation ${ }^{2,3}$

$$
\Phi_{u n k}=\Phi_{s t d}\left(\frac{I_{u n k}}{A_{u n k}}\right)\left(\frac{A_{s t d}}{I_{s t d}}\right)\left(\frac{\eta_{u n k}}{\eta_{s t d}}\right)^{2}
$$

where $u n k$ represents the sample, std represents the standard, $\Phi$ is the radiative quantum yield, $I$ is the integrated emission intensity, $A$ is the absorbance at the excitation wavelength, and $\eta$ is the refractive index of the solvent.

Luminescence lifetimes were measured with an IBH time-correlated single photon counting (TCSPC) system equipped with an IBH Model TBX-04 Photon Detection Module. The excitation source for the TCSPC measurements was a pulsed LED (IBH NanoLED, $370 \mathrm{~nm}, 1.2 \mathrm{~ns}$ pulse duration with a repetition rate of $1 \mathrm{MHz}$. All data was analyzed by iterative reconvolution of the decay profile $(10,000$ counts at the peak channel) with the instrument response function using software provided by the instrument manufacturer.

Molecular modeling was accomplished using HyperChem (2002) by Hypercube, Inc. Energy minimization used the AMBER force field (MM+).

\section{References}

(1) Tyson, D. S.; Ilhan, F.; Smith, D.; Meador, M. A. B.; Meador, M. A. Macromolecules 2005, 38, 3638. Ilhan, F.; Tyson, D. S.; Meador, M. A. Chem. Mater. 2004, 16, 2978.

(2) Dawson, W. R., Windsor, M. W. J. Phys.Chem.1968, 72, 3251.

(3) Damrauer, N. H.; Boussie, T. R.; Devenney, M.; McCusker, J. K. J. Am. Chem. Soc. 1997, 119, 8253. 